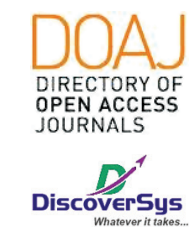

Published by DiscoverSys

\section{Hubungan antara perilaku duduk pengrajin ukir kayu dengan nyeri punggung bawah di Kecamatan Tegallalang, Gianyar, Bali}

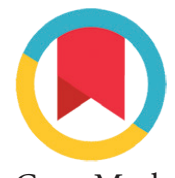

CrossMark

\author{
Pande Nyoman Dhandy Wirakesuma,${ }^{*}$ Anak Agung Sagung Sawitri, ${ }^{2}$ Komang Ayu \\ Kartika Sari ${ }^{2}$
}

\title{
ABSTRACT
}

Background: Low back pain is one of the health problems that are often encountered in workers. Some risk factors for low back pain are non-ergonomic sitting position, duration of work, working period, and rest breaks. Woodcarving craftsmen in Pupuan Village have a risk to experiencing low back pain complaint. The purpose of this study is determine whether sitting behaviors is related to low back pain.

Methods: An analytical observational study, designed in the form of a cross sectional study to determine the relationship between sitting behaviours with low back pain in Pupuan Village. Samples selected by a non-random consecutive sampling produced 69 samples and analysed using SPSS version 17.
Results: Most respondents complained of back pain (89.1\%), especially in the lower back (85.5\%), after work (95.2\%), and improved with changes in sitting position (95.2\%). The results of the bivariate analysis showed a significant relationship between age, sitting position, duration of work, length of work, and rest periods with complaints of low back pain $(\mathrm{P}<0.05)$.

Conclusion: There is a significant relationship between age, sitting position, duration of work, working period, and rest breaks with of low back pain complaint in wood carving craftsmen in Pupuan Village.

Keywords: Sitting position, Duration of work, Working period, Rest breaks, Low back pain

Cite This Article: Wirakesuma, P.N.D., Sawitri, A.A.S., Sari, K.A.K. 2019. Hubungan antara perilaku duduk pengrajin ukir kayu dengan nyeri punggung bawah di Kecamatan Tegallalang, Gianyar, Bali. Intisari Sains Medis 10(3): 649-654. D0I: 10.15562/ism.v10i3.475

\section{ABSTRAK}

Latar Belakang: Nyeri punggung bawah merupakan salah satu masalah kesehatan yang sering dijumpai pada pekerja. Beberapa faktor risiko terjadinya nyeri punggung bawah adalah posisi duduk yang tidak ergonomis, durasi kerja, masa kerja, dan jeda istirahat. Pengrajin ukir kayu di Desa Pupuan memiliki risiko untuk mengalami keluhan nyeri punggung bawah. Tujuan dari penelitian ini adalah untuk mengetahui apakah terdapat hubungan antara perilaku duduk dengan nyeri punggung bawah.

'Mahasiswa Pendidikan Dokter, Fakultas Kedokteran, Universitas Udayana, Bali, Indonesia ${ }^{2}$ Departemen IImu Kedokteran Komunitas dan Kedokteran Pencegahan (IKK/IKP), Fakultas Kedokteran, Universitas Udayana, Bali, Indonesia

*Korespondensi:

Pande Nyoman Dhandy Wirakesuma; Mahasiswa Pendidikan Dokter, Fakultas Kedokteran, Universitas Udayana, Bali, Indonesia; dhandy.pande@yahoo.com

Diterima: 03-04-2019

Disetujui: $15-07-2018$

Diterbitkan: 01-12-2019
Metode: Penelitian jenis analitik observasional, dirancang dalam bentuk studi potong lintang (cross sectional) untuk mengetahui hubungan antara perilaku duduk dengan nyeri punggung bawah di Desa

\section{PENDAHULUAN}

Indonesia termasuk negara yang memiliki jumlah angkatan kerja yang besar. Menurut data Badan Pusat Statistik (BPS) 2014 yang dikutip Kemenkes (2015) jumlah tenaga kerja di Indonesia mencapai 121,9 juta jiwa dan jumlah yang bekerja mencapai 114,6 juta jiwa (Kemenkes, 2015). ${ }^{1}$ Dilaporkan
Pupuan. Sampel dipilih secara non random jenis consecutive sampling menghasilkan 69 sampel dan dianalisis menggunakan SPSS versi 17.

Hasil: Sebagian besar responden mengeluhkan nyeri punggung $(89,1 \%)$, terutama pada punggung bagian bawah $(85,5 \%)$, setelah bekerja $(95,2 \%)$, dan membaik dengan perubahan posisi duduk $(95,2 \%)$. Hasil analisis bivariat menunjukkan adanya hubungan bermakna antara umur, posisi duduk, durasi kerja, masa kerja, dan jeda istirahat dengan keluhan nyeri punggung bawah $(P<0.05)$.

Kesimpulan: Terdapat hubungan bermakna antara umur, posisi duduk, durasi kerja, masa kerja, dan jeda istirahat terhadap keluhan nyeri punggung bawah pada pengrajin ukir kayu di Desa Pupuan.

Kata Kunci: Posisi duduk, Durasi kerja, Masa kerja, Jeda Istirahat, Nyeri punggung bawah

Cite Pasal Ini: Wirakesuma, P.N.D., Sawitri, A.A.S., Sari, K.A.K. 2019. Hubungan antara perilaku duduk pengrajin ukir kayu dengan nyeri punggung bawah di Kecamatan Tegallalang, Gianyar, Bali. Intisari Sains Medis 10(3): 649-654. D0I: 10.15562/ism.v10i3.475

pada International Labour Organization (ILO) bahwa satu pekerja meninggal setiap 15 detik akibat terjadi kecelakaan di tempat kerja dan setiap 15 detik terdapat 160 kecelakaan kerja yang terjadi di dunia. Kasus kecelakaan kerja di Indonesia sendiri mencapai 103.285 kasus pada $2013 .{ }^{2}$ 
Setiap pekerjaan memiliki risiko harm atau dampak buruk yang bervariasi dari ringan hingga berat. Pekerjaan pengrajin ukir kayu terlihat sederhana namun pekerjaan ini memiliki risiko terjadinya kecelakaan yang cukup besar. Alatalat yang digunakan dalam bekerja, cara bekerja dan kondisi lingkungan yang kurang tepat dapat menimbulkan berbagai risiko bagi para pekerja itu sendiri. Penggunaan alat seperti gergaji, palu, dan alat pemahat dapat menimbulkan luka. Kesalahan posisi duduk dapat juga menimbulkan berbagai macam keluhan fisik. Serta terhirupnya serbuk-serbuk kayu atau bahan kimia dari cat yang secara berlebihan dapat menimbulkan infeksi pada saluran pernafasan. Oleh karena tersebut, perlu dilakukan penelitian lebih lanjut untuk mencegah dan mengurangi kejadian kecelakaan kerja. ${ }^{3}$

Pengetahuan pengrajin akan pentingnya posisi duduk yang benar menjadi salah satu cara tercapainya Kesehatan dan Keselamatan Kerja (K3) bagi para pengrajin. Terdapat berbagai posisi duduk yang sering digunakan oleh para pengrajin yang dapat menimbulkan cidera otot, tulang, dan sendi. Faktor Repetition yaitu pekerjaan atau pergerakan dari tubuh yang dilakukan secara berulang yang dapat menyebabkan kelelahan. Faktor awkward posture yaitu posisi tubuh yang dianggap tidak biasa dan dipaksakan dalam waktu yang lama seperti kepala menunduk, menengadah, dan badan condong kedepan sangat mungkin menimbulkan cidera otot dan tulang. ${ }^{3}$

Angka kejadian NPB masih belum diketahui secara pasti di Indonesia. Penelitian yang dilakukan di Semarang pada tahun 2013 didapatkan bahwa sebanyak $35 \%$ pengrajin bekerja dengan posisi duduk yang tidak ergonomis dan sebanyak $60 \%$ pengrajin mengeluhkan nyeri punggung. ${ }^{4}$ Pada penelitian lain yang dilakukan di Jakarta pada pekerja dengan posisi duduk didapatkan sebanyak $63,2 \%$ mengeluhkan nyeri punggung bawah dan $69,2 \%$ keluhan dirasakan karena posisi duduk yang tidak ergonomis. ${ }^{5}$

Di Kecamatan Tegallalang, Kabupaten Gianyar banyak terdapat pengrajin ukiran kayu. Pengrajin tersebut umumnya tersebar di desa-desa. Skala industri dan pengrajin tersebut masih termasuk usaha kecil menengah dengan tempat kerja yang tidak luas. Berdasarkan observasi tempat pengrajin bekerja di Kecamatan Tegallalang, terlihat bahwa pengrajin masih banyak yang bekerja dalam posisi yang tidak benar, misalnya punggung terlalu membungkuk dan bekerja seharian penuh tanpa istirahat. Selain itu, pemberian informasi terkait perilaku kerja masih belum dilakukan secara menyeluruh oleh dinas kesehatan terkait sehingga beberapa sektor seperti pengrajin ukir kayu belum mendapatkan sosialisasi terkait perilaku kerja yang ergonomis. Dengan situasi tersebut, ada kemungkinan pengetahuan pengrajin masih rendah mengenai risiko nyeri punggung bawah (NPB) yang diakibatkan karena perilaku duduk. Belum adanya penelitian mengenai pengrajin ukir kayu di Kecamatan Tegallalang mendorong peneliti untuk mengamati lebih jauh mengenai kejadian NPB pada pengrajin ukir kayu yang akan di bahas pada bagian berikut.

\section{METODE PENELITIAN}

Penelitian ini menggunakan rancangan penelitian analitik observasional potong lintang (Crosssectional) terhadap 150 pengrajin ukir kayu menggunakan teknik consecutive sampling untuk mengetahui adanya hubungan antara posisi kerja, durasi kerja dan jeda istirahat terhadap nyeri punggung bawah pada pengrajin ukir kayu di Tegallalang, Gianyar Bali.

Beberapa parameter penelitia yang dinilai pada studi ini meliputi: 1) Masa kerja, merupakan jangka waktu dalam tahun yang dihitung sejak adanya hubungan kerja antara pekerja dan sejak pekerja pertama kali mulai bekerja berdasarkan pada perjanjian kerja sampai dengan penelitian ini dilaksanakan yang meliputi

$\leq$ rata-rata tahun) dan > rata-rata tahun; 2) Posisi duduk, merupakan posisi jarak vertical dari permukaan atas duduk sampai ujung atas kepala subyek, dengan memandang lurus kedepan dimana di nilai sebagai duduk tegak dan duduk condong kedepan $\left(>15^{\circ}\right)$; 3) Durasi kerja, rentang waktu atau lamanya pekerja dalam satu hari dengan posisi yang sama secara terus menerus diukur dengan satuan jam yang terbagi atas $<$ median jam dan $\geq$ median jam; dan 4) Jeda, merupakan waktu berhenti atau istirahat dari pekerjaan sementara dalam satu hari yang dihitung dalam menit dimana terbagi atas $<30$ menit dan lama $\geq 30$ menit

Penelitian ini menggunakan data primer, yaitu dengan kuesioner yang sudah tervalidasi sebagai instrument penelitian. Kuesioner dibuat berdasarkan data yang diperlukan dan yang ingin digali dari sampel. Data yang telah terkumpul dilakukan analisis dengan menggunakan perangkat lunak komputer. Analisis data yang telah dikumpul meliputi: Analisis Univariat, Bivariat, dan Multivariat menggunakan piranti lunak SPSS versi 17.

Penelitian ini telah mendapat persetujuan dari Komisi Etik Penelitian Fakultas Kedokteran Udayana/RSUP Sanglah sebelum dilaksanakan. Peneliti juga menerapkan informed consent dan prinsip kerahasian informasi pasien sebelum, selama, maupun sesudah penelitian berlangsung. 


\section{HASIL PENELITIAN}

Pada penelitian terhadap pengrajin ukir kayu lakilaki di Desa Pupuan, Kecamatan Tegallalang dari bulan Agustus hingga Oktober 2018, diikuti oleh 69 pengrajin ukir kayu yang kemudian dijadikan subjek penelitian. Pada responden tersebut didapatkan rata-rata umur 38,43 $\pm 10,97$ tahun dengan umur 17 tahun sebagai umur responden termuda dan umur 63 tahun sebagai umur responden tertua (Tabel 1).

Hasil pengolahan data univariat deskriptif didapatkan pengrajin lebih banyak bekerja dengan posisi membungkuk dibandingkan dengan posisi tegak. Masa kerja responden bervariasi, namun

Tabel 1 Gambaran sikap bekerja responden

\begin{tabular}{lcc}
\hline \multicolumn{1}{c}{ Variabel $(\mathbf{n = 6 9 )}$} & $\begin{array}{c}\text { Frekuensi } \\
\text { (Persentase (\%)) }\end{array}$ & $\begin{array}{c}\text { Rerata } \pm \text { SB / Median } \\
\text { (Min-Maks) }\end{array}$ \\
\hline $\begin{array}{l}\text { Posisi Duduk } \\
\text { Membungkuk }\left(>15^{\circ}\right)\end{array}$ & $59(85,5)$ & - \\
Tegak $\left(\leq 15^{\circ}\right)$ & $10(14,5)$ & - \\
Jeda Istirahat & & - \\
$<30$ menit & $38(55,1)$ & $22,64 \pm 11,15$ \\
$\geq 30$ menit & $31(44,9)$ & $7(2-10)$ \\
Masa Kerja (tahun) & - & $7(2-7)$ \\
Durasi Kerja (jam) & - & $2(1-3)$ \\
Hari Kerja per Minggu (hari) & - & \\
Jumlah Jeda Istirahat & - & \\
\hline
\end{tabular}

Tabel 2 Gambaran keluhan sakit responden

\begin{tabular}{lcc}
\hline Variabel (n=69) & Frekuensi & Persentase (\%) \\
\hline Nyeri Punggung & 62 & 89,9 \\
$\quad$ Ya & 7 & 10,1 \\
Tidak & & \\
Lokasi Nyeri Punggung & 51 & 73,9 \\
Punggung Bagian Atas & 35 & 50,7 \\
Punggung Bagian Tengah & 59 & 85,5 \\
Punggung Bagian Bawah & & \\
Waktu Nyeri Dirasakan & 1 & 1,6 \\
Sebelum Bekerja & 60 & 95,2 \\
Setelah Bekerja & 50 & 79,4 \\
Selama Bekerja & 18 & 28,6 \\
Tidak Tergantung Waktu & & \\
Perilaku Meringankan Keluhan & 24 & 38,1 \\
Minum Air & 60 & 9,5 \\
Berbaring di Tempat Tidur & 32 & 50,8 \\
Mengubah Posisi Duduk & & \\
Berhenti Bekerja Sejenak & 60,2 \\
\hline
\end{tabular}

Catatan: SB = Simpang Baku; Min = Nilai Minimum; Max = Nilai Maksimum sebagian besar pengrajin sudah bekerja selama 20 tahun lebih, bahkan terdapat pengrajin yang telah menekuni pekerjaan sebagai pengrajin ukir kayu selama 50 tahun. Pengrajin setiap bekerja setidaknya menghabiskan selama 2 jam untuk bekerja dan rata-rata pengrajin menghabiskan waktu selama lebih dari 6 jam dalam posisi duduk (Tabel 1).

Setiap minggu, pengrajin rata-rata menghabiskan 6 hari dalam satu minggu untuk bekerja mengukir kayu, bahkan terdapat pengrajin yang bekerja setiap hari sebagai pengrajin ukir kayu. Setiap kali bekerja, pengrajin akan beristirahat setidaknya 1 kali dan total waktu istirahat yang digunakan pengrajin lebih banyak dibawah 30 menit (Tabel 1).

Hasil pengolahan data terhadap keluhan responden menyatakan bahwa pengrajin banyak mengeluh nyeri punggung, bahkan hanya sebagian kecil yang tidak mengeluhkan nyeri punggung. Rata-rata nyeri yang dikeluhkan oleh pengrajin dirasakan sejak 21 bulan dengan 120 bulan sebelumnya merupakan waktu terlama dirasakan. Sebagian besar pengrajin mengeluhkan nyeri pada ketiga bagian punggung, yaitu punggung bagian atas, punggung bagian tengah, dan punggung bagian bawah, namun punggung bagian bawah merupakan titik yang paling banyak dikeluhkan pengrajin (Tabel 1).

Keluhan nyeri punggung banyak dirasakan selama bekerja maupun setelah bekerja, meskipun terdapat pengrajin yang telah mengeluhkan nyeri punggung sebelum bekerja dan tidak sedikit pula yang mengeluhkan nyeri punggung tidak tergantung waktu dirasakannya. Lebih dari 95\% dari jumlah pengrajin yang diwawancarai melakukan perilaku untuk meringankan keluhan dengan mengubah posisi duduk saat bekerja dan lebih dari sebagian pengrajin akan berhenti bekerja sejenak untuk meringankan keluhan nyeri punggung yang dirasakan (Tabel 2).

Hasil Uji independent-samples T-Test menunjukkan adanya perbedaan bermakna antara ratarata umur pada responden dengan keluhan nyeri punggung bawah (40,51 \pm 9,57 tahun) dan umur pada responden tanpa keluhan nyeri punggung bawah (26,20 $\pm 11,17$ tahun) dengan nilai $\mathrm{p}=0,000$ $(\mathrm{p}<0,05)$. Selain itu, ditunjukkan juga adanya perbedaan bermakna antara rata-rata masa kerja pada responden dengan keluhan nyeri punggung bawah $(24,86 \pm 9,5$ tahun $)$ dan masa kerja pada responden tanpa keluhan nyeri punggung bawah $(9,5 \pm 9,41$ tahun $)$ dengan nilai $\mathrm{p}=0,000(\mathrm{p}<0,05)$. Pada uji Mann Whitney yang dilakukan pada variabel durasi kerja juga didapatkan adanya perbedaan bermakna dilihat dari nilai rata-rata peringkat tiap kelompok yaitu, pada kelompok dengan keluhan 
Tabel 3 Perbedaan Rata-Rata pada Keluhan Nyeri Punggung

\begin{tabular}{lccc}
\hline Variabel & $\begin{array}{c}\text { Ya } \\
(\mathbf{n = 5 9 )}\end{array}$ & $\begin{array}{c}\text { Tidak } \\
(\mathbf{n}=\mathbf{1 0})\end{array}$ & $\mathbf{P}$ \\
\hline Umur (tahun) & $40,51 \pm 9,57$ & $26,20 \pm 11,17$ & $0,000^{\mathrm{a}^{*}}$ \\
Masa Kerja (tahun) & $24,86 \pm 9,5$ & $9,5 \pm 9,41$ & $0,000^{\mathrm{a}^{*}}$ \\
Durasi Kerja & 38,50 & 14,35 & $0,000^{\mathrm{b}^{*}}$ \\
\hline
\end{tabular}

Catatan: a = Dengan uji Independent-samples T Test $\mathrm{b}=$ Dengan uji Mann Whitney; ${ }^{*}=$ Memiliki perbedaan bermakna secara statistik (nilai $\mathrm{p}<0,05$ )

Tabel 4 Analisis Chi-Square Test terhadap Nyeri Punggung Bawah

\begin{tabular}{lccccc}
\hline & \multicolumn{2}{c}{ Nyeri Punggung Bawah } & & & \\
Variabel & Ya & Tidak & OR & $\mathbf{9 5 \%} \mathbf{~ C ~}$ & $\mathbf{p}$ \\
\cline { 2 - 3 } Posisi Duduk & & & & \\
$>15^{\circ}$ & $56(94,9 \%)$ & $3(5,1 \%)$ & & & \\
$\leq 15^{\circ}$ & $3(30 \%)$ & $7(70 \%)$ & & & \\
Jeda Istirahat & & & & & \\
$<30$ menit & $29(76,3 \%)$ & $9(23,7 \%)$ & $0,33-259,00$ & $0,000^{*}$ \\
$\geq 30$ menit & $30(96,8 \%)$ & $1(3,2 \%)$ & & $0,01-0,90$ & $0,016^{*}$ \\
\hline
\end{tabular}

Catatan: 1 cell (25\%) memiliki nilai harapan kurang dari 5; OR = Odd Ratio; $\mathrm{CI}=$ Confidence Interval; ${ }^{*}=$ Bermakna secara statistik ( $\mathrm{p}$ value $\left.<0,05\right)$

Tabel 5 Hasil Uji Regresi Logistik Biner

\begin{tabular}{lccc}
\hline Variabel & aOR & $\mathbf{9 5 \%} \mathbf{C l}$ & $\mathbf{P}$ \\
\hline Umur & 1.20 & $0.76-1.90$ & 0.438 \\
Posisi Duduk & 177.94 & $3.09-10257.83$ & $0.012^{\star}$ \\
Masa Kerja & 0.63 & $0.34-1.17$ & 0.145 \\
Durasi Kerja & 1.39 & $0.55-3.52$ & 0.464 \\
Jeda Istirahat & 0.01 & $0.00-4.45$ & 0.144 \\
\hline
\end{tabular}

Catatan: $\mathrm{aOR}=$ adjusted Odd Ratio; $\mathrm{CI}=$ Confidence Interval; ${ }^{*}=$ Bermakna secara statistik (nilai $\mathrm{p}<0.05$ )

\section{PEMBAHASAN}

Berdasarkan usia responden, didapatkan rerata umur pengrajin ukir kayu sebesar 38,43 tahun. Dengan usia termuda 17 tahun dan usia tertua 63 tahun. Pada penelitian Wiratma et al tahun 2014 didapatkan rerata pengrajin ukir kayu sebesar 39,82 tahun dengan rentangan antara umur 30 tahun sampai 49 tahun. ${ }^{6}$ Hasil yang menunjukkan rerata usia pengrajin yang tinggi diakibatkan oleh rendahnya minat pekerjaan pengrajin ukir kayu oleh generasi muda. Umur responden menunjukkan adanya hubungan yang signifikan dengan keluhan nyeri punggung bawah. Responden yang mengeluhkan nyeri punggung bawah memiliki rerata 40,51 tahun, sedangkan responden yang tidak memiliki keluhan nyeri punggung bawah dengan rerata 26,20 tahun. Hasil ini sejalan dengan penelitian Hidayat et al 2016 yang mendapatkan hasil bahwa sebagian besar pekerja yang berumur diatas 35 tahun memiliki risiko 9 kali mengalami keluhan muskuloskeletal. ${ }^{7}$ Pekerja akan mulai memiliki keluhan musculoskeletal pada umur 35 tahun dan akan terus meningkat seiring bertambahnya umur. Hal ini diakibatkan menurunnya kekuatan dan ketahanan otot seseorang seiring bertambahnya umur sehingga keluhan musculoskeletal dapat dirasakan. ${ }^{6}$

Masa kerja responden menunjukkan rerata 22,64 tahun. Dengan masa kerja terendah 2 tahun dan masa kerja tertinggi 50 tahun. Masa kerja yang tinggi diakibatkan pekerjaan yang telah ditekuni secara turun-temurun di wilayah tersebut. Analisis menggunakan Independent-samples $T$ Test menunjukkan bahwa terdapat hubungan yang signifikan antara masa kerja dengan keluhan nyeri punggung bawah. Rerata masa kerja yang memiliki keluhan nyeri punggung bawah sebesar 24,86 tahun, sedangkan rerata masa kerja yang tidak memiliki keluhan nyeri punggung bawah sebesar 9,5 tahun. Hasil ini menunjukkan bahwa semakin tinggi masa kerja pengrajin ukir kayu, maka keluhan nyeri punggung bawah semakin berisiko. Penelitian ini berbeda dengan penelitian Andreani et al yang mendapatkan hasil sebesar $72,7 \%$ responden telah bekerja selama $\leq 12$ tahun dan tidak adanya hubungan antara keluhan subjektif dengan masa kerja responden. ${ }^{8}$ Pada penelitian tersebut disebutkan bahwa proses adaptasi responden dan beban kerja yang tidak terlalu berat memengaruhi sedikitnya keluhan responden pada masa kerja tinggi. Hasil penelitian ini sesuai dengan penelitian Ramadhani et al yang mengatakan bahwa semakin lama masa kerja responden, semakin tinggi pula risiko untuk mengalami keluhan nyeri punggung. ${ }^{9}$ Semakin lama masa kerja pengrajin, maka semakin lama pula terpajan faktor risiko keluhan nyeri punggung bawah seperti posisi kerja 
yang tidak ergonomis yang telah dilakukan selama bertahun-tahun akan meningkatkan kecenderungan pengrajin untuk mengeluhkan nyeri punggung bawah. Nyeri punggung bawah merupakan penyakit kronis yang membutuhkan waktu yang lama untuk bermanifestasi sehingga semakin lama masa kerja, sehingga semakin banyak pula akumulasi beban kerja pengrajin yang akan menimbulkan kelelahan ataupun kekakuan otot yang pada akhirnya akan bergejala. ${ }^{9}$

Durasi kerja responden menunjukkan rerata 6,43 jam perhari dengan durasi kerja terendah 2 jam dan durasi kerja tertinggi 10 jam. Hasil uji Mann Whitney menunjukkan bahwa rerata peringkat durasi kerja yang memiliki keluhan nyeri punggung bawah sebesar 38,5, lebih tinggi dibandingkan rerata peringkat durasi kerja tanpa keluhan nyeri punggung bawah. Hasil tersebut juga menunjukkan adanya perbedaan bermakna secara statistik antara durasi kerja dengan keluhan nyeri punggung. Hasil ini sejalan dengan penelitian Zatadin et al yang menyebutkan bahwa terdapat hubungan secara statistik antara lama duduk dengan keluhan nyeri punggung bawah. ${ }^{10}$ Demikian juga pada penelitian Padmiswari et al yang mendapatkan adanya hubungan antara lama duduk dengan keluhan nyeri punggung bawah. ${ }^{11}$ Tingginya durasi kerja responden dikarenakan sebagian besar pengrajin bekerja membuat ukiran kayu di rumah sendiri sehingga sebagian besar waktunya dihabiskan untuk duduk bekerja. Semakin tinggi durasi kerja pengrajin, maka semakin lama pula pengrajin akan terpajan faktor risiko seperti posisi duduk yang tidak ergonomis. Aktivitas yang dilakukan secara terus menerus ini akan menimbulkan ketegangan otot sehingga akan menimbulkan gejala. ${ }^{11}$

Jeda istirahat responden menunjukkan bahwa sebanyak $55,1 \%$ memiliki waktu jeda istirahat kurang dari 30 menit selama bekerja. Analisis kai kuadrat juga menunjukkan adanya hubungan antara jeda istirahat dengan keluhan nyeri punggung bawah. Hasil ini berbeda dengan penelitian Belayana et al yang mendapatkan tidak adanya hubungan antara waktu istirahat dengan keluhan nyeri punggung bawah pada pengrajin ukir kayu. ${ }^{11}$ Pengrajin sedikit mendapatkan waktu untuk jeda istirahat disebabkan karena terlalu fokus bekerja sehingga tidak ingat waktu serta tidak ada yang mengawasi jam kerja pengrajin. Selain itu, pesanan yang menumpuk mengharuskan pengrajin untuk bekerja secara penuh sehingga waktu untuk istirahat digunakan untuk bekerja. ${ }^{11}$ Pada pengrajin yang memiliki waktu istirahat lebih dari 30 menit juga masih ada yang mengeluhkan nyeri punggung bawah. Hal ini disebabkan karena masih ada pengrajin yang tidak menggunakan waktu istirahat secara efektif, sebab kebanyakan waktu istirahat tersebut digunakan untuk melakukan kegiatan lainnya sehingga otot tidak mempunyai waktu untuk pemulihan dan penyegaran melainkan tetap tegang. Hal yang dilakukan secara terus menerus ini dapat menyebabkan terjadinya keluhan nyeri punggung bawah.

Sikap kerja responden menunjukkan sebesar $85,5 \%$ pengrajin bekerja dengan posisi membungkuk. Tingginya presentase tersebut disebabkan keharusan pengrajin untuk dapat bekerja lebih fokus dan teliti. Analisis kai kuadrat menunjukkan adanya hubungan yang signifikan antara posisi duduk dengan keluhan nyeri punggung bawah. Pengrajin yang bekerja dengan posisi duduk membungkuk memiliki risiko 42,56 kali untuk mengalami keluhan nyeri punggung bawah dibandingkan dengan pengrajin dengan posisi duduk tegak. Hasil ini sejalan dengan penelitian Septiawan yang mendapatkan adanya hubungan antara sikap kerja dengan keluhan nyeri punggung bawah. ${ }^{12}$ Demikian juga penelitian Andreani yang menunjukkan adanya hubungan antara sikap kerja responden dengan keluhan nyeri punggung bawah. ${ }^{8}$ Sebagian besar pengrajin bekerja dengan sesuka hati tanpa memperdulikan sikap kerja yang baik. Hal ini menyebabkan pengrajin bekerja dengan posisi yang salah. Posisi duduk condong kedepan akan memberikan beban yang lebih besar pada punggung sehingga ketegangan otot akan semakin tinggi. Sikap yang tidak ergonomis ini dilakukan pengrajin setiap bekerja sehingga lama-kelamaan otot yang menegang secara terus-menerus tersebut akan mulai kelelahan. Hal inilah yang akan menyebabkan keluhan dirasakan pengrajin saat bekerja ataupun setelah bekerja. Selain itu, tuntutan pekerjaan yang harus dilakukan dengan fokus dan ketelitian yang tinggi menyebabkan posisi tidak ergonomis ini akan tetap dilakukan sehingga keluhan nyeri punggung bawah pada pengrajin akan tetap dirasakan.

\section{SIMPULAN}

Berdasarkan hasil penelitian hubungan antara perilaku duduk pengrajin ukir kayu dengan nyeri punggung bawah di Kecamatan Tegallalang menunjukkan bahwa pada analisis bivariat ditemukan adanya hubungan antara variabel bebas yaitu umur, posisi duduk, durasi duduk, masa kerja, dan jeda istirahat terhadap keluhan nyeri punggung bawah pada pengrajin ukir kayu di Kecamatan Tegallalang.

\section{ETIKA PENELITIAN}

Penelitian ini telah mendapatkan persetujuan etik dari Komisi Etik Fakultas Kedokteran Universitas Udayana, Bali, Indonesia sebelum penelitian berjalan. 


\section{KONFLIK KEPENTINGAN}

Tidak ada

\section{PENDANAAN}

Penulis bertanggung jawab terhadap pendanaan penelitian ini tanpa melibatkan pihak sponsor, beasiswa, grant, atau sumber pendanaan lainnya

\section{KONTRIBUSI PENULIS}

Seluruh penulis memiliki kontribusi yang sama dalam penulisan penelitian ini baik dari tahap penyusunan proposal penelitian, pengumpulan data, analisis data, hingga laporan hasil penelitian.

\section{DAFTAR PUSTAKA}

1. Kementerian Kesehatan RI. Profil Kesehatan Indonesia 2014. 2015. Tersedia di : http://www.depkes.go.id [Diakses pada : 20 Juli 2016].

2. International Labour Organization (ILO). The Prevention of Occupational Diseases. Geneva: International Labour Organization. 2013

3. Simanjuntak RA. Penilaian Faktor-faktor Resiko Pada Saat Melakukan Pekerjaan Dengan Metode Manual Tasks Risk Assessment. Prosiding Seminar Nasional Aplikasi Sains \& Teknologi (SNAST) Periode III. 2012:A136-A143

4. Koesyanto H. Masa Kerja dan Sikap Kerja Duduk terhadap Nyeri Punggung. Jurnal Kesehatan Masyarakat. 2013;9(1):9-14

5. Maizura F. Faktor-Faktor yang Berhubungan dengan Keluhan Nyeri Punggung Bawah (NPB) pada Pekerja di PT Bakrie Metal Industries Tahun 2015. [Skripsi]. Universitas Islam Negeri Syarif Hidayatullah. Jakarta. 2015
6. Wiratma IKA, Adiputra LMISH. Gambaran Keluhan Muskuloskeletal pada perajin ukiran kayu di Kecamatan Manggis Kabupaten Karangasem. E-Jurnal Medika Udayana. 2015;4(10):1-12

7. Hidayat R, Hariyono W, Sutomo AH. Penyebab keluhan musculoskeletal pada perajin mebel ukir di Bantul. Berita Kedokteran Masyarakat. 2016;32(8):251-256

8. Andreani, MUD, Paskarini I. Sikap kerja yang berhubungan dengan keluhan subjektif pada penjahit di jalan patua Surabaya. Jurnal Promkes. 2013;1(2):201-208

9. Ramadhani AE, Sri W. Gambaran gangguan fungsional dan kualitas hidup pada pasien low back pain mekanik. Media Medika Muda. 2015;4(4):264-272

10. Zatadin ZM. Hubungan posisi duduk dan lama duduk terhadap kejadian nyeri punggung bawah (NPB) pada penjahit sektor informal di Kecamatan Laweyan Kota Surakarta. [Skripsi] Universitas Muhammadiyah Surakarta. 2018

11. Padmiswari NKS, Griadhi IPA. Hubungan Sikap Duduk dan Lama Duduk Terhadap Keluhan Nyeri Punggung Bawah Pada Pengrajin Perak Di Desa Celuk, Kecamatan Sukawati, Kabupaten Gianyar. E-Jurnal Medika Udayana. 2017;6(2):1-10

12. Belayana IBGB, Darmadi IGW, Mahayana IMB. Hubungan faktor waktu kerja, waktu istirahat, dan sikap kerja terhadap keluhan nyeri tengkuk pada pengerajin ukiran kayu. Jurnal Kesehatan Lingkungan. 2014;4(1):6-15

13. Septiawan H. Faktor yang berhubungan dengan keluhan nyeri punggung bawah pada pekerja bangunan di PT. Mikroland Property Development Semarang. [Skripsi] Universitas Negeri Semarang. 2013

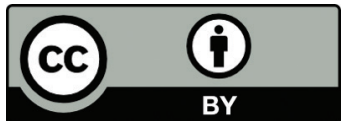

This work is licensed under a Creative Commons Attribution 